\title{
Do Men and Women Report Their Sexual Partnerships Differently? Evidence from Kisumu, Kenya
}

\begin{abstract}
CONTEXT: It is generally believed that men and women misreport their sexual behaviors, which undermines the ability of researchers, program designers and health care providers to assess whether these behaviors compromise individuals'sexual and reproductive health.
\end{abstract}

METHODS: Data on 1,299 recent sexual partnerships were collected in a 2007 survey of 1,275 men and women aged 18-24 and living in Kisumu, Kenya. Chi-square and t tests were used to examine how sample selection bias and selective partnership reporting may result in gender differences in reported sexual behaviors. Correlation coefficients and kappa statistics were calculated in further analysis of a sample of 280 matched marital and nonmarital couples to assess agreement on reported behaviors.

RESULTS: Even after adjustment for sample selection bias, men reported twice as many partnerships as women (0.5 vs. 0.2), as well as more casual partnerships. However, when selective reporting was controlled for, aggregate gender differences in sexual behaviors almost entirely disappeared. In the matched-couples sample, men and women exhibited moderate to substantial levels of agreement for most relationship characteristics and behaviors, including type of relationship, frequency of sex and condom use. Finally, men and women tended to agree about whether men had other nonmarital partners, but disagreed about women's nonmarital partners.

CONCLUSIONS: Both sample selection bias and selective partnership reporting can influence the level of agreement between men's and women's reports of sexual behaviors. Although men report more casual partners than do women, accounts of sexual behavior within reported relationships are generally reliable.

International Perspectives on Sexual and Reproductive Health, 2011,37(4):181-190, doi: 10.1363/3718111
By Shelley Clark, Caroline Kabiru and Eliya Zulu

Shelley Clark is associate professor, Department of Sociology, McGill University,

Montreal, Canada Caroline Kabiru is associate research scientist, African Population and Health Research Center, Nairobi, Kenya. Eliya Zulu is director, African Institute for Development Policy, Nairobi, Kenya.
In the wake of the HIV and AIDS pandemic-which has hit eastern and southern Africa particularly hard-knowing whether men and women accurately report their sexual behaviors has become increasingly important both to researchers seeking to understand how this epidemic has spread and to program designers attempting to identify ways to contain it. Nearly all previous studies have found marked gender differences in reported sexual behaviors, such as condom use, ${ }^{1-3}$ frequency of sex, ${ }^{4}$ relationship duration $^{5}$ and concurrent partners. ${ }^{2,3}$ Other research has found evidence of gender bias in the reported use of contraceptives among matched married couples. ${ }^{6,7}$ Several studies have found a particularly large gap between the average number of sexual partners reported by men and women. ${ }^{4,5,8,9}$ Although most research has suggested that these differences reflect a systematic tendency for men to exaggerate their number of partners and for women to underreport theirs, one study has argued that much of this difference is driven by a handful of men who grossly inflate their number of sexual encounters. ${ }^{10}$ Regardless of their source, these gender differences have led some researchers and many program designers to question the validity and usefulness of self-reported sexual behavior data. ${ }^{11}$ Yet aggregate gender differences in reported behaviors may not be entirely attributable to simple gender-based misreporting.
At least two other explanations for such gender differences are plausible. First, differences may stem from sample selection bias, which may occur if, on average, men have more sexual partners outside the study area than do women, have partners younger than the minimum age of sample respondents (typically age 15 or 18) or have partners, such as commercial sex workers, who are not likely to be interviewed in standard surveys. These types of bias would tend to inflate aggregate gender differences in both the average number of partners and other reported sexual behaviors, such as condom use, frequency of sex and relationship duration.

To limit the effects of sample selection bias, one study in Tanzania attempted to interview all men and women of reproductive age in four villages and restricted their sample of partners to those who resided in these villages and were the same age as the respondents (aged 15-64). ${ }^{5} \mathrm{Un}$ fortunately, since only $84 \%$ of eligible women and $77 \%$ of eligible men participated in the survey, the investigators could not entirely eliminate the potential for sample selection effects. Nonetheless, they found that, on average, women reported significantly fewer nonmarital sexual partners than men, as well as longer sexual relationships, leading them to conclude that in general men "swagger" (i.e., exaggerate their sexual activities), while women are 
"secretive" (i.e., underreport their sexual behaviors).

Matched-couple samples, unlike population-based surveys, guarantee that the partners of respondents are also interviewed. However, logistic challenges make finding a representative sample of matched partners difficult, and thus all such studies suffer from what Catania et al. ${ }^{12}$ refer to as "participation bias." Some forms of participation bias are obvious. For example, most matched-couple studies from low-income countries, including recent Demographic and Health Surveys, have been limited to married couples. ${ }^{13,14}$ Other sources of participation bias are less obvious, but equally important. Studies that include matched nonmarital couples in both North America and Africa often recruited their subjects from STI or other health clinics, thereby selecting "high-risk" couples, in which one or both members had sought treatment for a sexual or reproductive health problem. ${ }^{15-19}$ A few studies in developed countries used matched nonmarital couples drawn from population-based samples, ${ }^{20}$ yet to our knowledge, only one study has collected such data in the developing world. ${ }^{21}$ Unfortunately, matched-couple samples identified through population-based samples still suffer from participation bias because couples who agree to participate are likely to have closer, more serious or longer relationships. Consequently, such samples tend to minimize gender differences in reported sexual behaviors.

A second explanation for aggregate gender differences in reported sexual behaviors is that men and women selectively underreport or overreport specific types of partnerships. If sexual behaviors vary by type of partnership, then such selective reporting could lead to aggregate differences in behaviors, even if respondents accurately reported behaviors within specific partnerships. For example, if condoms are used more often in nonmarital than marital relationships, and if men are more likely than women to report nonmarital partnerships, then men will, on average, report more condom use. However, if male and female partners were asked to report about sexual behaviors within their specific relationship, they might provide similar responses.

In this article, we explore the effects of sample selection bias and selective partnership reporting on aggregate agreement in men's and women's reported sexual behaviors, using data on recent partnerships among youth in urban Kenya. In addition, we assess both aggregate agreement and intracouple concordance in a subsample of matched marital and nonmarital couples. These comparisons allow us to partially disentangle sources of gender bias in reported behaviors. A more nuanced understanding of the reliability and potential sources of bias in the reporting of behaviors in this at-risk population of youths is vital for both researchers and health care providers.

\section{METHODS}

\section{Data and Samples}

We used data collected in June and July of 2007 in Kisumu, the third largest city in Kenya and the migration hub of Nyanza province. According to the 2008-2009
Kenya Demographic and Health Survey, 22 Nyanza has the highest HIV prevalence in the country; among 15-24-yearolds, $8 \%$ are HIV-positive, compared with the national average of 3\%. We contacted every other household in 45 randomly selected urban enumeration areas in Kisumu, and men and women aged 18-24 were randomly assigned to receive one of two survey instruments, which contained identically worded questions about partner characteristics, relationship characteristics and sexual behaviors in the first and last month of the relationship. All questions were asked in face-to-face interviews with local trained interviewers. Ethical approval for this study was granted by the collaborating institutions. Further study details, descriptions of the survey instruments and a full analysis of gender differences in the reporting of sexual behaviors by instrument are reported elsewhere. ${ }^{23}$

In total, 1,275 men and women were interviewed, and respondents reported 1,299 sexual partnerships in the last year. To assess the effects of sample selection bias and participation bias, we created three samples. The "all partnerships" sample included the 1,299 reported partnerships. The "restricted partnerships" sample included only partners who met the age and residency restrictions of our respondents; hence, this category was limited to 487 reported partnerships in which the partners lived in Kisumu and were aged 18-24. Whereas the average ages of males and females in the total sample were similar (20.9 and 20.5 , respectively), in the restricted sample, females tended to be younger than males (18.5 vs. 20.5), suggesting that even in this narrow age-group, men selectively chose younger partners.

Finally, the "matched-couples" sample included all partners whom we interviewed and who were at least 18 years old and living in Kisumu. No respondent contributed more than one partnership to this sample. Eligible marital partners were approached directly unless the respondent asked us not to contact his or her spouse. Interviewing nonmarital partners, however, posed more challenges, as ethical considerations prevented us from directly approaching these individuals. For eligible nonmarital partners, respondents were asked whether they were willing to contact their partners and invite them to participate in the survey. If their partners agreed, the respondents told them how to contact the interview team. Both respondents and their partners were paid 200 shillings (about US\$3.00) for participating in the study; respondents were paid another 100 shillings (about US\$1.50) if their partner participated. Respondents and their partners were interviewed separately, and neither was informed that we would be evaluating the level of agreement between their responses.

Although interviewing nonmarital partners entailed little additional cost, it placed a greater onus on the respondents (who had to contact their partner) and on the partners (who had to contact the research team). Consequently, a large proportion of eligible partners were not interviewed, and those who were interviewed were selfselected. Figure 1 shows the proportions of partners who 


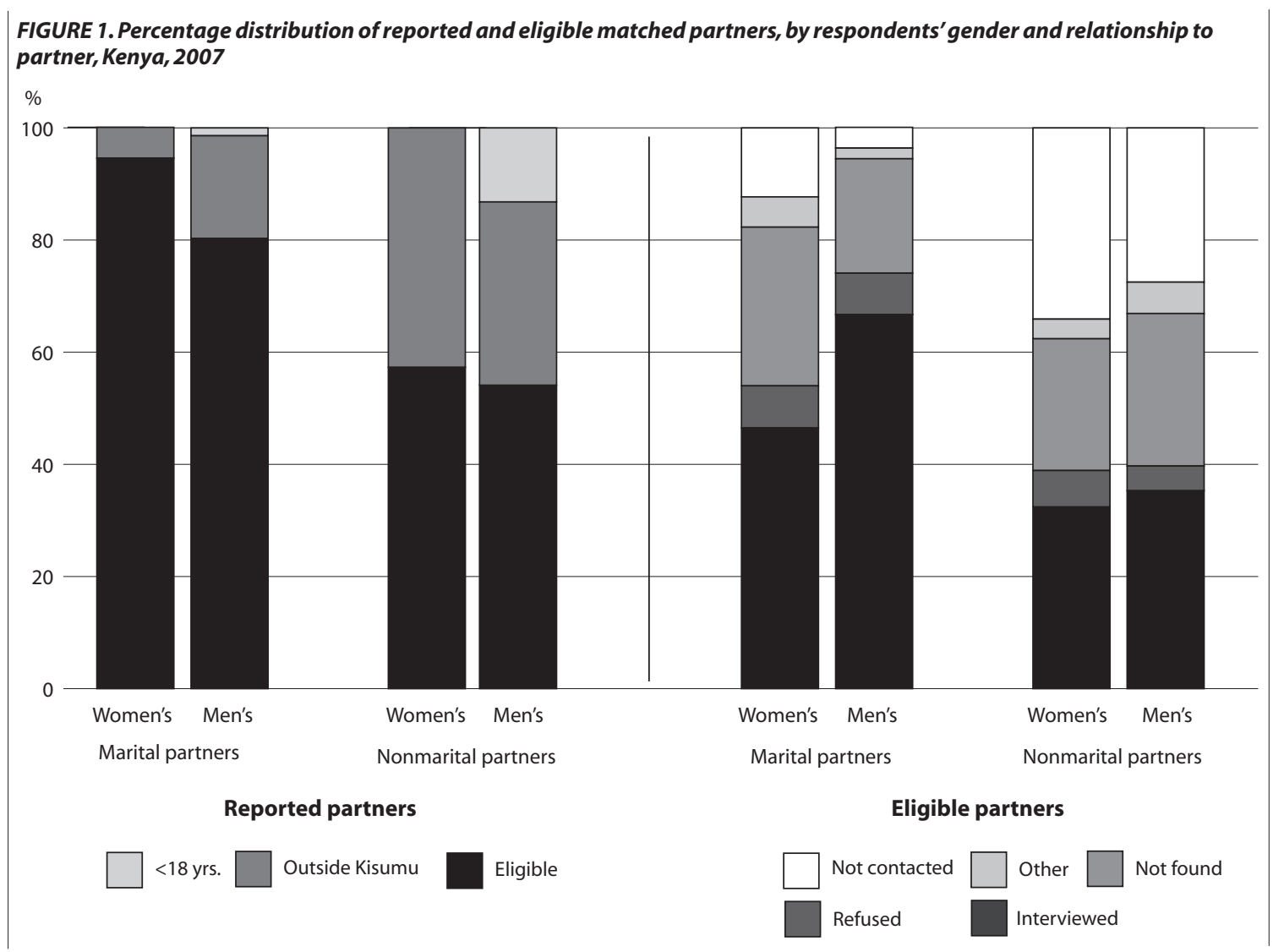

were eligible to be interviewed and, among those who were eligible, the proportions who were interviewed, by gender and by marital status. For both men and women, larger proportions of marital than nonmarital partners were eligible to be interviewed, as $43-46 \%$ of nonmarital partners either lived outside Kisumu or were younger than 18. Similarly, respondents were more willing to have their spouses than their nonmarital partners contacted, although $12 \%$ of women asked the research team not to contact their husband. Roughly equal proportions of marital and nonmarital partners could not be located (20-28\%) or refused to be interviewed (4-8\%). Similar proportions of women's and men's nonmarital partners were interviewed (32\% and 35\%, respectively), whereas a higher proportion of men's spouses than of women's spouses were interviewed (67\% vs. 47\%). Overall, 290 matched partners were interviewed. Of these, nine female partners and one male partner did not identify the index respondent as a sexual partner and so were dropped from the matched-couple analyses, leaving 280 matched partners.

\section{Measures}

All respondents and their partners provided social and demographic information about themselves and each of their sexual partners, including their age when the relationship began, educational attainment and ethnicity. Participants were also asked about relationship characteristics, including the duration of the relationship and whether one partner had given gifts or money to the other. In addition, they indicated whether, in the last month, each partner was a spouse, fiancé(e), serious girlfriend or boyfriend, dating partner, casual partner, one-night stand or commercial sex worker, or other type of partner (mainly separated or divorced partners).

Respondents reported the month of first intercourse, as well as the frequency of intercourse and of condom use for the first month of sexual activity and the last month of the relationship. * Frequency of sex per month was classified into four categories (zero, 1-4, 5-14 or at least 15 times), and frequency of condom use per month was classified into five categories (never, rarely, sometimes, mostly or always), which we recoded into three (never/rarely, sometimes/ mostly or always). Finally, we asked respondents whether they had had any concurrent nonmarital partners in the last month of their relationship, and whether they thought their partners had had any other nonmarital partners in the last month. Seventeen percent of both men and women said they did not know whether their partner had had other sexual partners, and these responses were combined with negative ones. ${ }^{\dagger}$

*Survey questions did not specify the type of intercourse, but in the few cases in which respondents asked for clarification, interviewers specified vaginal intercourse. Because anal sex remains a taboo topic among the sampled population, interviewers felt that all reports of intercourse referred to vaginal sex.

tWhen "don't know" responses were excluded from analyses, similar results were found. However, because we were interested in assessing how well participants' beliefs that their partners had had other partners matched reported behaviors, we focused on clear statements of partner infidelity. 


\begin{tabular}{|c|c|c|c|c|c|c|c|c|}
\hline \multirow[t]{3}{*}{ Characteristic } & \multicolumn{4}{|c|}{ All partnerships } & \multicolumn{4}{|c|}{ Matched couples } \\
\hline & \multicolumn{2}{|l|}{ Women } & \multicolumn{2}{|l|}{ Men } & \multicolumn{2}{|l|}{ Women } & \multicolumn{2}{|l|}{ Men } \\
\hline & $\begin{array}{l}\text { Not } \\
\text { restricted } \\
(\mathrm{N}=392)\end{array}$ & $\begin{array}{l}\text { Restricted } \\
(\mathrm{N}=157)\end{array}$ & $\begin{array}{l}\text { Not } \\
\text { restricted } \\
(\mathrm{N}=420)\end{array}$ & $\begin{array}{l}\text { Restricted } \\
(\mathrm{N}=330)\end{array}$ & $\begin{array}{l}\text { Not } \\
\text { interviewed } \\
(\mathrm{N}=226)\end{array}$ & $\begin{array}{l}\text { Interviewed } \\
(\mathrm{N}=141)\end{array}$ & $\begin{array}{l}\text { Not } \\
\text { interviewed } \\
(\mathrm{N}=244)\end{array}$ & $\begin{array}{l}\text { Interviewed } \\
(\mathrm{N}=149)\end{array}$ \\
\hline Partner's age (first month) & 24.6 & $20.5^{* * *}$ & 16.8 & $18.5^{* * *}$ & 24.0 & 23.1 & 18.3 & 17.9 \\
\hline Duration of relationship (mos.) & 36.2 & $25.9^{* * *}$ & 18.6 & 18.1 & 35.8 & 34.2 & 16.2 & 20.4 \\
\hline $\begin{array}{l}\text { Relationship ongoing } \\
\text { Type of relationship (last month) }\end{array}$ & 80.1 & 87.9 & 62.1 & $70.4^{*}$ & 82.9 & $97.9^{* * *}$ & 58.5 & $90.5^{* * *}$ \\
\hline Spouse & 39.5 & 34.4 & 6.2 & $14.5^{* * *}$ & 46.3 & $61.7^{* * *}$ & 8.0 & $24.2^{* * *}$ \\
\hline Fiancé(e) & 13.0 & 14.0 & 7.1 & 13.0 & 7.9 & 14.9 & 9.3 & 14.1 \\
\hline Serious boyfriend/girlfriend & 21.9 & 31.2 & 32.9 & 24.2 & 19.4 & 18.4 & 24.4 & 31.5 \\
\hline Dating partner & 14.5 & 12.7 & 19.8 & 18.5 & 13.4 & 2.8 & 17.8 & 13.4 \\
\hline Casual partner & 8.4 & 6.4 & 24.5 & 20.6 & 9.7 & 2.1 & 24.0 & 13.4 \\
\hline One-night stand/CSW & 0.5 & 0.0 & 8.1 & 7.9 & 0.0 & 0.0 & 16.0 & 2.0 \\
\hline Separated/other & 2.0 & 1.3 & 1.4 & 1.2 & 3.2 & 0.0 & 0.4 & 1.3 \\
\hline Man gave woman gifts/money & 82.1 & 82.8 & 66.1 & $75.5^{* *}$ & 85.6 & 79.4 & 70.7 & 78.4 \\
\hline Woman gave man gifts/money & 43.6 & 44.9 & 45.0 & 48.6 & 40.7 & 41.4 & 42.9 & 47.0 \\
\hline
\end{tabular}

\section{Analysis}

To test for sample selection bias, we compared partner and relationship characteristics of partnerships in our restricted sample (i.e., partners aged 18-24 and living in Kisumu) with those of partnerships that were excluded from this sample (i.e., partners not in this age-group or residing outside Kisumu). We evaluated participation bias by comparing the partners who were interviewed (i.e., those in the matched-couples sample) with those who were eligible but were not interviewed-because they were not contacted by the respondent, not found or refused to be interviewed. To assess selective partnership reporting, we compared the number and type of sexual relationships reported by men and women in both the all-partnerships and restrictedpartnerships samples. Although the all-partnerships sample suffers from selection bias and, hence, the mean number of partners reported by men and women could differ, in the restricted-partnerships sample, their average number and type of partnerships theoretically should be the same.

To explore whether sample selection is primarily responsible for the gender differences in sexual behaviors that are often reported, we compared the level of aggregate agreement by gender in our all-partnerships and restricted samples across a variety of behaviors. If sample selection bias is driving these differences, then agreement between men's and women's reported behaviors should be greater in the restricted sample than in the sample of all partnerships. We would expect to find the greatest agreement in our matched-couples sample, which eliminates selection bias, but may overstate agreement between partners because it suffers from participation bias. Finally, we assessed the degree to which selective partner reporting is responsible for differences in other reported sexual behaviors by testing whether gender differences persist after controlling for type of relationship reported in our sample of all partnerships. In the all-partnerships and restrictedpartnerships samples, aggregate gender differences were assessed using chi-square tests for categorical variables and $t$ tests for continuous ones. Z tests were used to assess differences in the all-partnerships adjusted sample. In our matched-couples sample, we used McNemar's statistic for dichotomous variables, chi-square tests for other categorical variables and Wilcoxon signed rank tests for continuous variables to account for the paired reporting of the same sexual behaviors.

In addition to assessing aggregate differences, we also evaluated the level of agreement (or concordance) between men's and women's reports of partner characteristics, relationship characteristics and sexual behaviors in matched couples. Agreement was measured by both the crude agreement and Cohen's kappa for all categorical variables. Crude agreement, which is the total percentage of men and women who agree across all response categories, is highly dependent on the number of categories. Kappa statistics are generally considered to be a better measure of concordance, because they determine whether the level of agreement is significantly higher than the level expected to occur by chance. However, these statistics are known to underestimate agreement for events with very low or very high probabilities. ${ }^{18}$ In general, kappa coefficients indicate weak agreement when between 0.00 and 0.20 , fair agreement between 0.21 and 0.40 , moderate agreement between 0.41 and 0.60 , substantial agreement between 0.61 and 0.80 , and strong to nearly perfect agreement above 0.80. ${ }^{15}$ Kappa statistics indicate interpartner reliability, but they cannot determine whether one or the other partner is telling the truth. Pairwise correlation coefficients were used to assess the level of agreement for the continuous variables (partner's age, mean relationship duration, month of first sex and mean number of months before first sex). 


\begin{tabular}{|c|c|c|c|c|c|c|}
\hline \multirow[t]{2}{*}{ Characteristic } & \multicolumn{3}{|c|}{ All partnerships } & \multicolumn{3}{|c|}{ Restricted partnerships } \\
\hline & Women & Men & $\begin{array}{l}\text { Men/women } \\
\text { ratio }\end{array}$ & Women & Men & $\begin{array}{l}\text { Men/women } \\
\text { ratio }\end{array}$ \\
\hline No.of respondents & 643 & 632 & na & 643 & 632 & na \\
\hline No.of partnerships & 549 & 750 & na & 157 & 330 & na \\
\hline Mean no. of partnerships & 0.85 & $1.19^{* * *}$ & 1.40 & 0.24 & $0.52^{* * *}$ & 2.14 \\
\hline \multicolumn{7}{|c|}{ Type of relationship (last month, mean) } \\
\hline Spouse & 0.33 & $0.12^{* * *}$ & 0.36 & 0.08 & 0.08 & 1.00 \\
\hline Fiancé(e) & 0.11 & 0.12 & 1.09 & 0.03 & $0.07^{* *}$ & 2.33 \\
\hline Serious boyfriend/girlfriend & 0.21 & $0.34^{* * *}$ & 1.62 & 0.08 & $0.13^{* *}$ & 1.63 \\
\hline Dating partner & 0.12 & $0.23^{* * *}$ & 1.92 & 0.03 & $0.10^{* * *}$ & 3.33 \\
\hline Casual partner & 0.07 & $0.27^{* * *}$ & 3.86 & 0.02 & $0.11^{* * *}$ & 5.50 \\
\hline One-night stand/CSW & 0.00 & $0.09 * * *$ & na & 0.00 & $0.04^{* * *}$ & na \\
\hline Separated/other & 0.02 & 0.02 & 1.00 & 0.00 & 0.01 & na \\
\hline
\end{tabular}

\section{RESULTS}

\section{Selection and Participation Bias}

To assess selection bias in the all-partnerships sample, we compared reports from respondents in the restricted sample with those from respondents who were excluded from this group. Partners of women in our restricted sample were, on average, younger than those who were excluded from that sample ( 21 vs. 25-Table 1 ) because a large proportion of women's reported partners were older than 24 . By contrast, the partners of men in the restricted sample were older (19 vs. 17), as many of their reported partners were younger than 18. Men's partnerships in the restricted sample were more likely to be ongoing (70\% vs. 62\%) and, on average, lasted as long as relationships that were excluded from the sample. For women, however, partnerships in the nonrestricted sample tended to be of longer duration than those in the restricted group (36 vs. 26 months). We found large and significant differences by type of relationship between the two partner samples for men, but not between the partner samples for women. In addition, men were more likely to have provided gifts or money to partners in the restricted sample than to those in the nonrestricted sample (76\% vs. $66 \%$ ).

We also found clear evidence of participation bias in our matched-couples sample. Although no significant differences in partners' ages or relationship duration were found, men's and women's relationships with partners who were interviewed were far more likely than those with partners who were not interviewed to be ongoing (91\% vs. $59 \%$ for men, and $98 \%$ vs. $83 \%$ for women). For both men's and women's partners, those who were interviewed were more likely to be married or engaged to the respondent, and less likely to be casual partners, than those who were not interviewed.

\section{Selective Reporting of Partnerships}

In the full sample, men reported, on average, $40 \%$ more sexual relationships than did women (means, 1.2 vs. 0.9Table 2). In the restricted sample, men had more than twice as many sexual partners as women, although the mean number of partners for each gender was lower $(0.5$ vs. 0.2). The increased discrepancy was due primarily to the greater exclusion of women's reported partners than of men's reported partners.

In the full sample, the ratio of partners reported by men to those reported by women increased monotonically as the type or relationship became more casual (from 0.4 for spouses to 3.9 for casual partners): Women reported, on average, nearly three times as many spouses as men, whereas men reported nearly four times as many casual partners as women. In the restricted sample, however, we found no evidence of gender bias in the reporting of marital partners, but found stronger bias in the reporting of nonmarital partners (from a ratio of 2.3 for fiancé(e)s to 5.5 for casual partners). These results suggest that either women are underreporting nonmarital partners or men are overreporting them, or both.

\section{Differences in Sexual Behaviors}

In the full sample of all reported partnerships, men and women provided significantly different accounts across all measures of sexual behaviors (Table 3, page 186). On average, women reported waiting longer than men to have sex within a relationship (five vs. four months), but also said they had engaged in sex more frequently than men: Twenty-five percent of women and 16\% of men reported having had sex 5-14 times in the last month of the relationship, and $12 \%$ and $8 \%$, respectively, reported having had sex 15 or more times in the last month. Men were more likely than women to report having ever used condoms ( $76 \%$ vs. $65 \%$ ), more likely to report having always used them during the first month of the relationship (56\% vs. $41 \%$ ) and during the previous month (29\% vs. $17 \%$ ), and less likely to report never having used them during those months. Interestingly, while 17\% of women in the full sample said they thought their partner had other nonmarital partners, $25 \%$ of men reported having had more than one nonmarital partner in the last month of their relationship. By comparison, 25\% of men suspected that their partner had other nonmarital partners, whereas only $7 \%$ of women reported having a concurrent nonmarital partner. 


\begin{tabular}{|c|c|c|c|c|c|c|c|c|}
\hline \multirow[t]{2}{*}{ Measure } & \multicolumn{2}{|c|}{ All partnerships } & \multicolumn{2}{|c|}{ Restricted partnerships } & \multicolumn{2}{|c|}{$\begin{array}{l}\text { All partnerships } \\
\text { (adjusted) }\end{array}$} & \multicolumn{2}{|c|}{ Matched couples } \\
\hline & $\begin{array}{l}\text { Women } \\
(\mathrm{N}=549)\end{array}$ & $\begin{array}{l}\text { Men } \\
(\mathrm{N}=750)\end{array}$ & $\begin{array}{l}\text { Women } \\
(\mathrm{N}=157)\end{array}$ & $\begin{array}{l}\text { Men } \\
(\mathrm{N}=330)\end{array}$ & $\begin{array}{l}\text { Women } \\
(\mathrm{N}=549)\end{array}$ & $\begin{array}{l}\text { Men } \\
(N=750)\end{array}$ & $\begin{array}{l}\text { Women } \\
(\mathrm{N}=280)\end{array}$ & $\begin{array}{l}\text { Men } \\
(\mathrm{N}=280)\end{array}$ \\
\hline \multirow{2}{*}{\multicolumn{9}{|c|}{ Frequency of sex (first month) }} \\
\hline & & & & & & & & \\
\hline 1-4 times & 57.5 & $62.9^{*}$ & 57.4 & 62.6 & 59.0 & 61.5 & 10.1 & 10.8 \\
\hline $5-14$ times & 30.8 & 29.8 & 34.8 & 29.2 & 31.2 & 29.7 & 22.7 & 30.6 \\
\hline$\geq 15$ & 11.8 & 7.3 & 7.7 & 8.2 & 9.7 & 8.9 & 67.2 & 58.6 \\
\hline \multicolumn{9}{|l|}{ Frequency of sex (last month) } \\
\hline 0 & 31.4 & $41.6 * * *$ & 24.4 & 31.7 & 35.7 & 38.2 & 16.9 & 17.9 \\
\hline $1-4$ times & 31.8 & 34.0 & 34.0 & 37.2 & 33.2 & 32.9 & 27.0 & 23.3 \\
\hline $5-14$ times & 24.5 & 16.3 & 29.5 & 20.1 & 20.6 & 19.4 & 39.6 & 40.5 \\
\hline$\geq 15$ & 12.4 & 8.2 & 12.2 & 11.0 & 10.5 & 9.6 & 16.6 & 18.3 \\
\hline Used any contraceptive (first month) & 67.0 & 71.4 & 69.4 & 72.5 & 72.0 & 67.4 & 62.8 & 62.5 \\
\hline \multicolumn{9}{|l|}{ Used condoms (first month) } \\
\hline Rarely/never & 43.7 & $31.4^{* * *}$ & 41.0 & $31.6^{* *}$ & 38.7 & 34.9 & 43.7 & 46.4 \\
\hline Sometimes/mostly & 15.7 & 13.0 & 18.0 & 11.9 & 14.5 & 14.1 & 16.9 & 16.4 \\
\hline Always & 40.6 & 55.6 & 41.0 & 56.5 & 46.9 & 51.0 & 39.4 & 37.1 \\
\hline \multicolumn{9}{|l|}{ Used condoms (last month) } \\
\hline No sex & 31.6 & $41.1^{* * *}$ & 25.8 & $31.4^{* * *}$ & 36.2 & 37.5 & 17.6 & 20.4 \\
\hline Rarely/never & 43.5 & 23.7 & 47.7 & 28.1 & 32.0 & 31.9 & 49.6 & 50.4 \\
\hline Sometimes/mostly & 8.2 & 6.6 & 9.7 & 7.0 & 7.4 & 7.3 & 11.5 & 11.1 \\
\hline Always & 16.6 & 28.7 & 16.8 & 33.5 & 24.3 & 23.4 & 21.2 & 18.2 \\
\hline Ever used condoms & 64.5 & $75.7^{* * *}$ & 68.0 & $76.4^{*}$ & 70.1 & 71.7 & 62.7 & 60.7 \\
\hline Man had other nonmarital partnert & 17.3 & $25.1^{* * *}$ & 17.2 & 20.9 & 20.4 & 22.4 & 10.7 & 12.9 \\
\hline Woman had other nonmarital partnerł & 6.7 & $25.1^{1 * *}$ & 6.4 & $25.5^{* * *}$ & 9.5 & $21.0^{* * *}$ & 3.9 & $8.2^{*}$ \\
\hline
\end{tabular}

In the restricted sample-designed to minimize the effects of sample selection-we found no significant differences regarding time until first sex, frequency of sex and men's involvement with concurrent nonmarital partners. On average, however, men were still more likely to report using condoms, and the proportion of men who believed that their partner had another nonmarital partner was greater than the proportion of women who reported having such partners ( $26 \%$ vs. $6 \%$ ).

To account for our findings in Table 2 that men and women systematically reported different types of sexual relationships, we assessed gender differences in reported behaviors after controlling for the type of relationship (Table 3). We found that men and women gave strikingly similar descriptions of their behaviors; only women's reports of their nonmarital partners remained significantly different from men's suspicions ( $10 \%$ vs. $21 \%$ ).

Finally, in comparing aggregate agreement among matched couples, we found only one significant gender difference: Men were twice as likely to suspect their female partners of having other nonmarital partners (8\%) as women were to report such partnerships (4\%). Notably, the proportion of women who suspected that their partners had other nonmarital partners was similar to the proportion of men who reported having such partners (11\% and $13 \%$, respectively). In addition, when men and women were referring to the same partnership, there was no systematic gender bias regarding time until first sex, frequency of sex, or use of condoms or other contraceptives. All of these matched-couple results, however, should be in- terpreted with caution, as Table 1 shows that this sample overrepresents relationships that were ongoing and of a more serious nature.

\section{Interpartner Agreement and Concordance}

By first assessing the level of agreement and concordance within matched partnerships of presumably objective and nonsensitive traits, such as age, ethnicity and educational attainment, we can determine not only how well couples know each other, but whether one gender is better informed than the other about their partner's characteristics. Among all matched couples, we found that exceptionally high proportions of both men and women (more than $90 \%$ ) gave the same answer as their partner about the partner's ethnicity (Table 4). Women appeared to be more accurate than men at reporting their partner's age (correlation coefficients, 0.8 vs. 0.6 ), and although three-quarters of each gender agreed with their partner's assessment of their level of education, the kappas indicate only a moderate level of concordance ( 0.6 for each).

Nearly all respondents agreed about whether the relationship was ongoing, but as often occurs with kappas, the high prevalence of ongoing relationships (95\%) coincided with a rather low kappa (0.4). There was a strong and significant correlation ( 0.8 ) between men's and women's reports about the duration of the relationships. The level of agreement about the type of relationship in the last month was moderate ( $71 \%$ ). More than $80 \%$ of men and women agreed on whether gifts or money had been given by one partner to the other. 


\begin{tabular}{|c|c|c|c|c|c|c|}
\hline \multirow[t]{2}{*}{ Measure } & \multicolumn{2}{|c|}{$\begin{array}{l}\text { All matched couples } \\
(\mathrm{N}=280)\end{array}$} & \multicolumn{2}{|c|}{$\begin{array}{l}\text { Married couples } \\
(\mathrm{N}=120)\end{array}$} & \multicolumn{2}{|c|}{$\begin{array}{l}\text { Unmarried couples } \\
(\mathrm{N}=160)\end{array}$} \\
\hline & $\begin{array}{l}\text { Crude } \\
\text { agreement }\end{array}$ & $\begin{array}{l}\text { Kappa/ } \\
\text { corr.coeff. }\end{array}$ & $\begin{array}{l}\text { Crude } \\
\text { agreement }\end{array}$ & $\begin{array}{l}\text { Kappa/ } \\
\text { corr.coeff. }\end{array}$ & $\begin{array}{l}\text { Crude } \\
\text { agreement }\end{array}$ & $\begin{array}{l}\text { Kappa/ } \\
\text { corr.coeff. }\end{array}$ \\
\hline \multicolumn{7}{|l|}{$\begin{array}{l}\text { Partners' characteristics } \\
\text { Age }\end{array}$} \\
\hline Men & na & $0.75^{* * *}$ & na & $0.81^{* * *}$ & na & $0.68^{* * *}$ \\
\hline Women & na & $0.63^{* * *}$ & na & $0.61^{* * *}$ & na & $0.61^{* * *}$ \\
\hline \multicolumn{7}{|l|}{ Ethnicity } \\
\hline Men & 97.5 & $0.92^{* * *}$ & 99.2 & $0.98^{* * *}$ & 96.3 & $0.88^{* * *}$ \\
\hline Women & 92.8 & $0.82^{* * *}$ & 97.5 & $0.93^{* * *}$ & 89.3 & $0.76^{* * *}$ \\
\hline \multicolumn{7}{|l|}{ Education } \\
\hline Men & 73.3 & $0.56^{* * *}$ & 78.8 & $0.63^{* * *}$ & 69.1 & $0.46^{* * *}$ \\
\hline Women & 75.9 & $0.57^{* * *}$ & 88.2 & $0.73^{* * *}$ & 66.5 & $0.38^{* * *}$ \\
\hline \multicolumn{7}{|l|}{ Relationship characteristics } \\
\hline Mean relationship duration (mos.) & na & $0.80^{* * *}$ & na & $0.86^{* * *}$ & na & $0.74 * * *$ \\
\hline Relationship ongoing & 94.6 & $0.37^{* * *}$ & 100.0 & na & 90.5 & $0.35^{* * *}$ \\
\hline Type of relationship (last month) & 71.0 & $0.59^{* * *}$ & 100.0 & na & 49.1 & $0.29 * * *$ \\
\hline Man gave woman gifts/money & 83.5 & $0.51^{* * *}$ & 84.0 & $0.50 * * *$ & 83.0 & $0.51^{* * *}$ \\
\hline Woman gave man gifts/money & 82.8 & $0.65^{* * *}$ & 85.0 & $0.67^{* * *}$ & 81.1 & $0.62^{* * *}$ \\
\hline \multicolumn{7}{|l|}{ Sexual behavior } \\
\hline Mean no. of mos. before first sex & na & $0.44^{* * *}$ & na & 0.12 & na & $0.77^{* * *}$ \\
\hline Month of first sex & na & $0.75^{* * *}$ & na & $0.81^{* * *}$ & na & $0.62^{* * *}$ \\
\hline Frequency of sex (first month) & 61.1 & $0.25^{* * *}$ & 58.1 & $0.30^{* * *}$ & 63.3 & $0.18^{* *}$ \\
\hline Frequency of sex (last month) & 62.5 & $0.48^{* * *}$ & 65.6 & $0.52^{* * *}$ & 60.1 & $0.40^{* * *}$ \\
\hline Used any contraceptive (first month) & 77.9 & $0.53^{* * *}$ & 70.8 & $0.39^{* * *}$ & 83.6 & $0.49^{* * *}$ \\
\hline Used condoms (first month) & 68.8 & $0.50 * * *$ & 74.8 & $0.50 * * *$ & 64.4 & $0.41^{* * *}$ \\
\hline Used condoms (last month) & 70.9 & $0.56^{* * *}$ & 81.5 & $0.46^{* * *}$ & 62.9 & $0.50 * * *$ \\
\hline Ever used condoms & 81.0 & $0.60^{* * *}$ & 79.8 & $0.58^{* * *}$ & 81.9 & $0.47^{* * *}$ \\
\hline Man had other nonmarital partner† & 85.0 & $0.28^{* * *}$ & 94.2 & $0.43^{* * *}$ & 78.1 & $0.21^{* *}$ \\
\hline Woman had other nonmarital partnerł & 88.5 & 0.01 & 95.8 & 0.00 & 83.1 & 0.01 \\
\hline
\end{tabular}

We were particularly interested in the reporting of sexual behaviors, since a lack of agreement would indicate that such behaviors were not reported reliably. Although men and women, on average, reported identical durations until first sex (3.4 months, see Table 3), the interpartner correlation coefficient was only 0.4 . The correlation was substantially higher (0.8) for men's and women's reports of the month of first sex. Although these relationships began an average of more than two years before the survey, further analyses indicated that $39 \%$ of men and women gave exactly the same month of first sex, while more than $60 \%$ gave dates within three months of each other (not shown). More than $60 \%$ of men and women reported the same frequency of sexual intercourse, but this reflected only fair agreement in the first month and moderate agreement in the last month (kappas, 0.3 and 0.5 , respectively). All measures of condom and other contraceptive use demonstrated moderate levels of agreement; crude agreement ranged from $69 \%$ for the frequency of condom use in the first month to $81 \%$ for whether condoms were ever used. Although sexual behaviors are typically considered more sensitive and, hence, prone to greater misreporting, men and women showed roughly the same level of agreement on several of these measures as they did on less sensitive measures, such as partner's educational attainment.

In $85 \%$ of relationships, women's suspicions regarding whether their partners had other nonmarital partners concurred with men's reports of such partners, corresponding to a fair level of agreement (kappa, 0.3). When we removed all women who said they did not know whether their partners were exclusive, the kappa rose to 0.4 (not shown). In contrast, although the crude level of agreement between men's suspicions that their partner had another nonmarital partner and their partner's report of having another partner was high, reflecting the small proportion of women who reported such partners, there was no agreement overall between women's reports and men's suspicions. Indeed, this was the only sexual behavior measure for which men's and women's reports were not significantly higher than the level that would have been expected by chance.

Finally, we examined the level of crude agreement and concordance among matched married and unmarried couples. As expected, married couples generally exhibited higher levels of agreement and concordance regarding their partner's age, education and ethnicity. However, because relationships of married couples had lasted an average of one and a half years longer than those of unmarried couples (not shown), recall bias may have affected the reporting of events that occurred at the beginning of these relationships. Accordingly, married couples had a much lower correlation coefficient ( 0.1$)$ than did unmarried cou- 
ples (0.8) for the mean number of months before first sex. Yet for most other measures of relationship characteristics and sexual behavior, married couples generally had higher levels of agreement than unmarried couples. Notably, unmarried partners were less likely to agree about the frequency of sex and about whether men had other nonmarital partners.

\section{DISCUSSION}

Prevailing wisdom contends that misreporting of both the number of sexual partners and sexual behaviors themselves is the primary cause of aggregate gender differences. Researchers commonly attribute such differences to deliberate misreporting as a result of social desirability bias, and argue that women tend to underreport behaviors that carry a stigma for them, while men may overreport behaviors that are associated with prestige or sexual prowess. ${ }^{12,24}$ Consequently, much current research focuses on developing new survey methods to reduce social desirability bias and improve reporting of sensitive sexual behaviors. There has been a surge of interest in using computer-assisted self-interview (CASI) techniques (such as audio-CASI) as a means of improving the validity of sexual behavior reporting. In a systematic review, Langhaug et al. ${ }^{25}$ found that use of audio-CASI generally increased the reporting of sensitive sexual behaviors, particularly among females, compared with self-administered questionnaires or face-to-face interviews (including those using ballot cards). However, the effectiveness of audio-CASI can vary considerably across study sites, and it often fails to increase the reporting of sensitive behaviors. ${ }^{26-28}$

Consistent with findings from other studies, our results showed large and significant gender differences in the number and type of reported sexual partners. Sample selection bias accounted for the gender differences in the number of marital partners, but not in the number of nonmarital partners. Even after adjusting for selection bias, we found that young men reported twice as many nonmarital partners as did young women. Unlike previous studies, however, our research found that sample selection bias accounted for gender differences in about half of the other sexual behavior measures. In addition, when we controlled for gender bias in the reported type of relationship, we found no evidence of aggregate gender bias in any of the other measures, except for women's reported number of concurrent nonmarital partners relative to men's suspicion of such partnerships. This finding was further confirmed by the lack of any statistically significant differences between men's and women's reported sexual behaviors in our matched-couples sample, with the exception of women's concurrent nonmarital partners.

The most important limitation of our study is that the matched-couple sample suffers from participation bias, and so the level of interpartner agreement may be biased upward because this sample overrepresents relationships that are ongoing and more serious. Nonetheless, we found substantial agreement on reported sexual behaviors with- in these partnerships. Compared with other matchedcouple studies in North America and Europe, which also reflect participation bias, Kenyan matched couples exhibit similar levels of concordance regarding the date of first sex, ${ }^{29}$ the frequency of sex ${ }^{19,30}$ and condom use. ${ }^{15-19,31}$ Another limitation of the study is that, even though high levels of agreement between men's and women's reports of sexual behaviors indicate that these are reliable measures, we cannot assess the validity or truthfulness of these reports.

Although there was considerable gender bias in the reported number of nonmarital sexual partners, the reporting of sexual behaviors within specific partnerships was not subject to extensive gender bias. In practical terms, these findings can be useful to health care providers, program designers and researchers. For designers and providers seeking to assess an individual's sexual and reproductive health risks, reported sexual behavior within a partnership is likely to be reliable. Nonetheless, given that the optimal strategy to prevent the spread of several STIs entails testing and treating all sexual partners, our findings suggest that special care is required when inquiring about nonmarital sexual partners. For researchers, these findings point to the need to improve the accuracy with which the number of nonmarital partnerships is reported, perhaps by employing audio-CASI and ballot box survey methods. However, such methods are likely not needed to obtain reasonably accurate responses to other sensitive questions, such as frequency of sex, condom use, men's infidelity or the receipt of money or gifts within a relationship. Instead, additional matched-couple surveys of nonmarital sexual partnerships, followed by qualitative probes, may be most useful in determining why some partners provide different answers. Studies of young nonmarital and marital matched couples in Sub-Saharan Africa are especially critical, because women face their greatest risk of acquiring HIV during adolescence and young adulthood. Such research would improve our understanding not only of differences in the reporting of sexual behaviors, but also of the relationships between these behaviors and sexual and reproductive health outcomes in this vulnerable population

\section{REFERENCES}

1. Prata N, Vahidnia F and Fraser A, Gender and relationship differences in condom use among 15-24-year-olds in Angola, International Family Planning Perspectives, 2005, 31(4):192-199.

2. Mnyika KS et al., Determinants of high-risk sexual behaviour and condom use among adults in the Arusha region, Tanzania, International Journal of STD \& AIDS, 1997, 8(3):176-183.

3. Meekers D and Klein M, Determinants of condom use among young people in urban Cameroon, Studies in Family Planning, 2002, 33(4): 335-346.

4. Smith TW, Adult sexual behavior in 1989: number of partners, frequency of intercourse and risk of AIDS, Family Planning Perspectives, 1991, 23(3):102-107.

5. Nnko $S$ et al., Secretive females or swaggering males?: an assessment of the quality of sexual partnership reporting in rural Tanzania, Social Science \& Medicine, 2004, 59(2):299-310. 
6. Miller K, Zulu EM and Watkins SC, Husband-wife survey responses in Malawi, Studies in Family Planning, 2001, 32(2):161-174.

7. Ezeh AC and Gora M, Estimates and explanations of gender differentials in contraceptive prevalence rates, Studies in Family Planning, 1997, 28(2):104-121.

8. Todd J et al., Reported number of sexual partners: comparison of data from four African longitudinal studies, Sexually Transmitted Infections, 2009, 85(Suppl. 1):i72-i80.

9. Konings E et al., Sexual behaviour survey in a rural area of northwestern Tanzania, AIDS, 1994, 8(7):987-993.

10. Morris M, Telling tails explain the discrepancy in sexual partner reports, Nature, 1993, 365(6445):4.

11. Brody S, Patients misrepresenting their risk factors for AIDS, International Journal of STD \& AIDS, 1995, 6(6):392-398.

12. Catania JA, A framework for conceptualizing reporting bias and its antecedents in interviews assessing human sexuality, Journal of Sex Research, 1999, 36(1):25-38.

13. Lagarde E, Enel C and Pison G, Reliability of reports of sexual behavior: a study of married couples in rural West Africa, American Journal of Epidemiology, 1995, 141(12):1194-1200.

14. Anglewicz P et al., HIV risks among currently married couples in rural Malawi: What do spouses know about each other? AIDS \& Behavior, 2010, 14(1):103-112.

15. Harvey SM et al., He said, she said: concordance between sexual partners, Sexually Transmitted Diseases, 2004, 31(3):185-191.

16. Stoner BP et al., Avoiding risky sex partners: perception of partners' risks $v$ partners' self reported risks, Sexually Transmitted Infections, 2003, 79(3):197-201.

17. Sison JD, Gillespie B and Foxman B, Consistency of self-reported sexual behavior and condom use among current sex partners, Sexually Transmitted Diseases, 2004, 31(5):278-282.

18. Ochs EP and Binik YM, The use of couple data to determine the reliability of self-reported sexual behavior, Journal of Sex Research, 1999, 36(4):374-384.

19. The NIMH Multisite HIV/STD Prevention Trial for African American Couples Group, Concordant and discordant reports on shared sexual behaviors and condom use among African American serodiscordant couples in four cities, AIDS and Behavior, 2010, 14(5):1011-1022.

20. Bearman PS, Moody J and Stovel K, Chains of affection: the structure of adolescent romantic and sexual networks, American Journal of Sociology, 2004, 110(1):44-91.

21. Helleringer S and Kohler H-P, Sexual network structure and the spread of HIV in Africa: evidence from Likoma Island, Malawi, AIDS, 2007, 21(17):2323-2332.

22. Kenya National Bureau of Statistics (KNBS) and ICF Macro, Kenya Demographic and Health Survey, 2008-09, Calverton, MD, USA: KNBS and ICF Macro, 2010.

23. Luke N, Clark S and Zulu EM, The relationship history calendar: improving the scope and quality of data on youth sexual behavior, Demography, 2011, 48(3):1151-1176.

24. Bignami-Van Assche S, Are we measuring what we want to measure? Individual consistency in survey response in rural Malawi, Demographic Research, 2003, Special Collection 1, Art. 3, <http://www. demographic-research.org/special/1/3/sl-3.pdf>, accessed Sept. 16, 2011.

25. Langhaug L, Sherr L and Cowan F, How to improve the validity of sexual behavior reporting: systematic review of questionnaire delivery modes in developing countries, Tropical Medicine $\&$ International Health, 2010, 15(3):362-381.

26. Jaya HM and Ahmed S, Differences in young people's reports of sexual behaviors according to interview methodology: a randomized trial in India, American Journal of Public Health, 2008, 98(1):169-174.

27. Mensch BS, Hewett PC and Erulkar A, The reporting of sensitive behavior by adolescents: a methodological experiment in Kenya, De- mography, 2003, 40(2):247-268

28. Mensch B et al., Sexual behavior and STI/HIV status among adolescents in rural Malawi: an evaluation of the effect of interview mode on reporting, Poverty, Gender, and Youth Working Papers, New York: Population Council, 2008, No. 8.

29. Brewer D et al., Agreement in reported sexual partnership dates and implications for measuring concurrency, Sexually Transmitted Diseases, 2006, 33(5):277-283.

30. Witte S et al., Predictors of discordant reports of sexual and $\mathrm{HIV} /$ sexually transmitted infection risk behaviors among heterosexual couples, Sexually Transmitted Diseases, 2007, 34(5):302-308.

31. Seal DW, Interpartner concordance of self-reported sexual behavior among college dating couples, Journal of Sex Research, 1997, 34(1):39-55.

\section{RESUMEN}

Contexto: Existe la creencia generalizada de que los hombres y mujeres proporcionan información errónea sobre sus comportamientos sexuales, lo cual disminuye la capacidad de investigadores, diseñadores de programas y proveedores de servicios de salud para evaluar si esos comportamientos ponen en riesgo la salud sexual y reproductiva.

Métodos: Datos sobre 1,299 relaciones de pareja se recolectaron en una encuesta basada en la población, aplicada a 1,275 hombres y mujeres en edades de 18-24 años, que viven en Kisumu, Kenya. Se usaron pruebas Chi-cuadrada y pruebas t para examinar la forma en que los sesgos de selección muestral y los reportes selectivos pueden resultar en diferencias de género en los comportamientos sexuales reportados a nivel de análisis colectivo. Adicionalmente, se calcularon los coeficientes de correlación y estadísticas kappa en otro análisis de una muestra de 280 parejas conyugales y no conyugales coincidentes, para evaluar el acuerdo sobre los comportamientos reportados dentro de la pareja.

Resultados: Aun después de ajustar por sesgo muestral, los hombres reportaron el doble de relaciones de pareja que las mujeres ( promedios de parejas al año de 0.5 vs. 0.2), así como más parejas casuales. Sin embargo, cuando se controló el reporte selectivo, las diferencias de género en los comportamientos sexuales a nivel de analisis colectivo casi desaparecieron por completo. En las muestras de parejas coincidentes, tanto hombres como mujeres exhibieron niveles de acuerdo dentro de la pareja desde moderados hasta sustanciales para la mayoría de las características y comportamientos de la relación, incluido el nivel de compromiso, la frecuencia de las relaciones sexuales y el uso del condón. Finalmente, tanto hombres como mujeres tuvieron tendencia a estar de acuerdo sobre si el hombre tenía otras parejas fuera del matrimonio, pero estuvieron en desacuerdo sobre las parejas de las mujeres fuera del matrimonio.

Conclusiones: Tanto el sesgo de selección muestral como los reportes selectivos de parejas pueden influir en el nivel de acuerdo a nivel colectivo entre los informes de hombres y mujeres referentes a los comportamientos sexuales, y los hombres reportan más parejas casuales que las mujeres. Sin embargo, los informes sobre el comportamiento sexual dentro de una pareja en general son confiables. 


\section{RÉSUMÉ}

Contexte: Il est généralement admis que les hommes et les femmes déclarent faussement leurs comportements sexuels, limitant ainsi la capacité des chercheurs, concepteurs de programmes et prestataires de soins de santé à évaluer la mesure dans laquelle ces comportements compromettent ou non la santé sexuelle et génésique de l'individu.

Méthodes: Les données relatives à 1.299 partenariats sexuels récents ont été collectées dans le cadre d'une enquête menée en 2007 auprès de 1.275 hommes et femmes âgés de 18 à 24 ans et vivant à Kisumu (Kenya). La manière dont le biais de sélection de l'échantillon et la déclaration sélective de partenariat peuvent donner lieu à une déclaration différente des comportements sexuels en fonction du genre a été examinée par tests chi carré et t. Les coefficients de corrélation et les statistiques kappa ont été calculés dans l'analyse ultérieure d'un échantillon de 280 couples conjugaux et non conjugaux assortis, afin d'évaluer l'accord sur les comportements déclarés.

Résultats: Même après correction du biais de sélection, les hommes déclarent deux fois le nombre de partenariats déclaré par les femmes $(0,5$ par rapport à 0,2$)$. Ils déclarent aussi plus de partenariats de passage. Toutefois, sous contrôle de la déclaration sélective, les différences de genre globales concernant les comportements sexuels disparaissent presque totalement.
Dans l'échantillon de couples assortis, les hommes et les femmes présentent des niveaux d'accord moyens à considérables concernant la plupart des caractéristiques et comportements de la relation, y compris le type de relation, la fréquence des rapports sexuels et l'usage du préservatif. Enfin, les hommes et les femmes ont tendance à s'accorder sur la question de savoir si les hommes ont d'autres partenaires non conjugales, mais pas sur celle des partenaires non conjugaux des femmes.

Conclusions: Le biais de sélection et la déclaration sélective de partenariat peuvent tous deux influencer le niveau d'accord entre les déclarations de comportements sexuels masculines et féminines. Bien que les hommes déclarent plus de partenaires de passage que les femmes, les rapports de comportements sexuels au sein des relations déclarées sont généralement fiables.

\section{Acknowledgments}

Funding for this research was provided by National Institutes of Health/National Institute of Child Health and Human Development grant 5R21HD053587-02. The authors thank Nancy Luke for her leadership in the data collection, and Rohini Mathur and Cassandra Cotton for their excellent assistance in preparing the tables.

Author contact:shelley.clark@mcgill.ca 